\title{
MIGRATION AND IDENTITY: A CASE OF EMIRDAG AND POSOF- ORIGIN PEOPLE IN BELGIUM ${ }^{12}$
}

\author{
GÖÇ VE KİMLIKK: BELÇİKA’DAKİ EMIRDAĞ VE POSOFLULAR ÖRNEĞİ
}

\section{Öz}

Filiz GÖKTUNA YAYLACI ${ }^{3}$

$\mathrm{Bu}$ çalışmanın amacı, Emirdağ ve Posoflular örneğinde Belçika'da yaşayan Türklerin kimlik ve aidiyet duygularını, kimliklerinin ulus ötesi boyutlarını irdelemektir. Veri toplamak amacıyla nitel ve nicel araştırmak teknikleri bir arada kullanılmıştır. Belçika'da yaşayan 55 kişi ile görüşme yapılmış, 424 kişinin katılımıyla anket uygulaması yapılmıştır. Araştırmacı Belçika'daki dokuz aylık alan araştırması sürecinde aynı zamanda katılımlı gözlemler gerçekleştirerek fotoğraflar çekmiştir. Derinlemesine görüşmelerden, SPSS analizlerinden ve katılımlı gözlemlerden elde edilen sonuçlar çalışmanın amaçları doğrultusunda alanyazın 1şı̆̆ında yorumlanmıştır. Bulgular, katılımcıların kendilerini "Belçikalı Türk" olarak değil öncelikle ve çoğunlukla "Türk" olarak tanımladıklarını göstermektedir. Bu tanımlamanın, kendi kültürleri ile birlikte Belçika'da Türk olarak var olmaya yönelik çabaların sonucu olduğu söylenebilir.

Anahtar Kelimeler: Göç, Kimlik, Belçika, Belçika’daki Türkler

\begin{abstract}
The purpose of this study is to examine perceptions of Turks in Belgium about their identity and their sense of belonging, transnational aspects of their identities in the sample of the people who have Emirdag and Posof origins. In order to collect data, qualitative and quantitative research techniques were used. Living in Belgium, 55 people were interviewed and 424 people were surveyed. The researcher spent a 9-month research visit to Belgium, conducted participatory observations and took photos in the field. Data from in-depth interview and participatory observation techniques, as well as data from SPSS analyses were analyzed and interpreted on the basis of literature and in line with purposes of the study. Findings show that they define themselves primarily and mostly as a "Turk" not as "Belgian Turks." It's seen that defining themselves as Turk is caused by the efforts aimed at existing in Belgium along with their own culture.
\end{abstract}

Key Words: Migration, Identity, Belgium, Turks in Belgium

\footnotetext{
${ }^{1}$ This study consists of some part of a doctoral dissertation by Filiz GÖKTUNA YAYLACI entitled "Understandings of Particularism and Social Communication of Turkish People Living in Belgium: A Research on Turkish People Who Have Emirdag and Posof Origins" ${ }^{2}$ An earlier version of this article was presented at the V th European Conference on Social and Behavioral Sciences September 11-14, 2014 - Baltic Institute of Humanities, St Petersburg, Russia

${ }^{3}$ Filiz GÖKTUNA YAYLACI is an Assistant Professor in the Sociology Department, Anadolu University, Eskişehir,Turkey, E-mail: fgoktuna2@yahoo.com
} 


\section{Introduction}

The rapid improvement which occurred in communication technologies in the last century has interconnected all over the world with each other and caused a radical transformation in human society. The developments in communication technologies such as increased access to inexpensive mobile phones, etc. created an impact on transnational societies and intensified migrants' communications with their family members (Vertovec, 2004; Chen, 2005). This process which has also influenced and shaped the migrants' identities is experienced in a global environment which is shaped by the dissolution of traditional political and societal structures, as observed by Peters and Faist (2003). In such a dynamic atmosphere, the symbolic borders, cultural differences and ethnic conflicts also gain more importance and different meanings as well. The multiple identities, as well as identities in fields which are not limited by countries, cultures or geographical conditions are currently mentioned. As Martin and Nakayama (2007) stated the identities are the conceptualizations of individuals about who they are. The identities are processed; they are in a state of process and exposed to ongoing transformations and increasing disintegration (Hall and Du Gay, 1996; Shi, 2005). According to Hall, individuals have a complicated perception regarding identity as a result of global conditions which are experienced. The ethnic and cultural diversity, various nationalisms and the process of globalization which take place in most of the countries contribute to this confusion as well. Many people have multiple identities at the same time (Haralambos and Holborn, 1995: 715). As indicated by Maalouf (2009), the identities were replaced by ideologies and societies started to guide political events in today's world which could be defined as "fields of civilizations" in conflict.

The problem about identity of migrants is complicated due to the very nature of migration process and there are in a sense multiple identities which are occasionally compliant and noncompliant with each other (Orozco and Garcia-Zanello, 2009). The authorities currently think that the migrants are greatly influenced by their ties with their homelands, as well as the social ties crossing social borders. The requirement for a transnational point of view with regard to migration is also mentioned (Lewitt and Glick Schiller, 2004: 1). As emphasized by Orozco and Garcia-Zanello (2009), international or transnational migration and globalization have been transforming the individuals and the societies surrounding them, particularly the relations between migrants and their homelands or host countries. Bunnell's finding is considerably correct (2010: 477); "Today Malay migrants in Liverpool are not so much "outside" the Malay world or South Asia." All of the migrants exist simultaneously in the country of origin and in the host country just like the migrants of Malaysian origin in Britain. Migrants live in various crosscutting social networks (Gielis, 2009: 274). The national network is just one of them. As a result, today it would be preferable to talk about trans-social migrants and there are three types of applications in terms of nationality types, namely, the international, multicultural and national nationality (Soysal, 1994 cited in Şahin, 2010). There are some conceptualizations such as transnational migrants and trans-migrants. In this respect, "transnational processes" are defined as processes in which the migrants construct social fields that connect the country they come from with the country they live in (Gielis, 2009). The transformations related with migrants' locations recently caused the development of various definitions and concepts in literature. The important conceptualizations such as transnational communities (Portes, 1996), transnational circuits (Rouse, 1989), transnational networks (Hannerz, 1996), transnational social fields (cited in Levitt and Glick Schiller, 2004) and transnational social spaces (Faist, 2000) highlight the significance of migrants' locations in an original field which connects the two countries and societies in a transnational context (Gielis, 2009: 272). The multiple contexts defined as the 'transnational social field' (Glick 
Schiller et al. 1992), 'transnational social space' (Pries, 1999), 'transnational village' (Levitt, 2001) or 'translocality' (Appadurai 1995) presents a complex set of conditions that construct, negotiate and reproduce social identities in the multi-local life-world (quoted by Vertovec, 2001: 578). In this sense, trans-nationality provides a productive and effective approach in terms of understanding the migrant identity. At this point, the migrant identity is not considered within the contexts of source and target country-culture and shaped by them. (Bunnell, 2010). This approach aims at going beyond the distinction between the sender and receiver country with a focus on multifaceted relations maintained by individuals in multiple countries (Zontini, 2010). The migrant identity and qualities of a transnational life shape the atmosphere they live in, their life styles and habits; the transnational qualities in their lives constitute an important research subject. Gielis (2009: 274) has also stressed the importance of focusing on places in which the migrants live. People perceive their social worlds as places like house, workplace, neighborhood, etc. Each social network consists of unique placeslocations. The migrants' places like the house, etc. are defined as "translocality" by Appadurai, consisting of many nations and cultures such as the nation of origin, the country they live in, etc. Furthermore, virtual platforms such as the Internet are established (Gielis, 2009). Transnational ties are used in a great many studies within the concept of the migrants' activities in many fields ranging from economic activities to politics, religion, location and media. A study analyses Turks' transnational ties in Germany as part of nationality and transnational activities and defines the transnational activities to cover relations with relatives in Turkey, the place where they live in Germany, ethnic markets, media, neighborly relations, memberships to non-governmental organizations, political participations, holiday preferences and recreational activities (Şahin, 2010). In this case, it could be argued that the lives of migrants in destination countries are transnational and that each sphere of their lives encompasses the reflections of transnational ties. The transnational countries consist of migrants and their relatives and friends. These communities facilitate harmony with the new country and also ensure that the symbolic and actual relations with the country of origin are maintained (Djelic and Quack, 2010). In literature, various adjectives were created to define the migrants of Turkish origin who have migrated to Europe. Accordingly, the aim was to express considerably complex characteristics of the designation of a migrant. Such definitions as Euro-Turks, European Turks or on the basis of countries the Belgian Turks have been created to a great extent in recent years in order to define identities in a multifaceted way (Kaya and Kentel, 2008). Turkish people in Belgium who constitute the research subject encompass unique characteristics in terms of belonging as well. In this context, the purpose of this study is to analyze Belgian Turks' identity perceptions, the way they define themselves and their sense of belonging and transnational characteristics of their identities. In this respect, the interviewees' opinions on how they define themselves, which community they feel like they belong to, how often they visit Turkey, as well as their views about returning to Turkey, staying in Belgium and acquiring Belgian citizenship.

\section{Method}

For collecting collect data, qualitative and quantitative research techniques were used in the research. The research sample encompasses a group of migrants who were chosen from the migrant people from Afyon-Emirdag and Ardahan-Posof who live in Belgium and attract attention with their characteristics of settlement in the form of clustering and constitute more than half of the Turkish population in Belgium. There are more than 180,000 people or their families who have migrated from Turkey to Belgium (Turkish Embassy in Brussels, 2014). According to information compiled from managements of associations established by the migrants from Emirdag and Posof and also prominent figures of communities, nearly 10,000 
people from Posof live in entire Belgium. Furthermore, the number of people from Emirdag exceeds 100,000. Within the context of population and sample calculations, a sample of 383 persons is foreseen for a population of 100,000 people, as well as a sample of 384 persons for a population of 500,000 people is foreseen in a confidence interval of .05 (Cing1, 1994: 25, quoted by Büyüköztürk et al., 2008). Considering that there are approximately 200,000 people of Turkish origin in Belgium who constitute the population of the study and the number of people in the group from Emirdag and Posof is nearly 110,000, it was agreed that the elements such as the working conditions, practicability, feedbacks from questionnaires, etc. will be taken into consideration and the sample will consist of 450 persons on whom the scale is applied. As a result of the application, 424 out of a total of 450 questionnaires were fully filled in and taken into the scope of analysis, and face-to-face interviews were made with 55 people. The application of questionnaire and interviews were conducted in Anvers, Gent, Willebroek, Lier and Heusden-Zolder and Brussels, the capital, in the Flemish region of Belgium. The interviewees' answers were mentioned in the form of direct quotes, which are shown by code names designated to interviewees. Data from in-depth and participatory observation techniques and data from SPSS analyses were analyzed and interpreted in line with the purpose of study.

\section{Findings}

Table 1 shows information regarding demographic features of interviewees. The 55 interviewees included 33 persons from Emirdag, 20 persons from Posof and other 2 Turks. 32 interviewees are from the first generation and 23 interviewees are from the second generation. The interviewees are composed of 27 females and 28 males.

Table 1-Interviewees' Localities and Genders

\begin{tabular}{lllll}
\hline & Emirdag & Posof & Other Turk & Total \\
\hline Gender & $\mathrm{f}$ & $\mathrm{f}$ & $\mathrm{f}$ & $\mathrm{f}$ \\
Female & 20 & 7 & - & 27 \\
Male & 13 & 13 & 2 & 28 \\
TOTAL & 33 & 20 & 2 & 55 \\
\hline
\end{tabular}

As seen on Table 2, 102 participants of the questionnaire from Emirdag (48\%) are female and 112 of them are male $(52 \%)$ based on their localities. Furthermore, 82 interviewees from Emirdag (39\%) are female and 128 of them are male (61\%)

Table 2-Localities and Genders of Participants of Questionnaire

\begin{tabular}{lllllll}
\hline & Emirdag & & Posof & \multicolumn{3}{c}{ Total } \\
\hline Gender & f & $\mathbf{\%}$ & $\mathbf{f}$ & $\mathbf{\%}$ & $\mathbf{f}$ & $\mathbf{\%}$ \\
Female & 102 & 47,7 & 82 & 39,0 & 184 & 43,4 \\
Male & 112 & 52,3 & 128 & 61,0 & 240 & 56,6 \\
TOTAL & $\mathbf{2 1 4}$ & $\mathbf{1 0 0}$ & $\mathbf{2 1 0}$ & $\mathbf{1 0 0}$ & $\mathbf{4 2 4}$ & $\mathbf{1 0 0}$ \\
\hline
\end{tabular}




\section{Findings on Self-Definition}

In the questions covered by the questionnaire part of the study, the alternatives were not predetermined to be presented to participants, but the alternatives were grouped on the basis of answers. According to the Chi-square analysis results (Table 3) with regard to their differentiation in terms of locality, gender and generation as part of the opinions of participants of the questionnaire on self-definition, it is seen that the majority of them $(70 \%)$ define themselves as a "Turk." The rate of those who define themselves as a Belgian or a Belgian Turk is quite low (only 2 persons). As for localities, their self-definition of a Turk ranks the highest in the two groups. One-tenth of migrants from Emirdag define themselves as someone from Emirdag (13\%), whereas the rate of migrants from Posof who define themselves as someone from Posof is higher. One fourth of migrants from Posof define themselves as someone from Posof $(26 \%)$. It is seen that the opinions on self-definition include significant differences in terms of gender $\left(X^{2}{ }_{(5)}=9,13 \mathrm{p} .000<.02\right) .65 \%$ of females define themselves as a Turk, whereas this rate is $74 \%$ among males. Similarly, $25 \%$ of females and $15 \%$ of males define themselves as people from Emirdag or Posof in terms of locality. A significant difference was not found with regard to generations $\left(\mathrm{X}^{2}{ }_{(10)}=42,38\right.$ p.000< .05). The term "Turkish" ranked the highest in three generations as a way of selfdefinition. $79 \%$ of migrants from the first generation, $62 \%$ of the second generation and $47 \%$ of the third generation defined themselves as a Turk. The rate of self-definition of someone from Emirdag and Posof is $14 \%$ in the first generation, $13 \%$ in the third generation and $25 \%$ in the second generation. The rate of self-definition of a Belgian or a Belgian Turk is considerably low. Only $1 \%$ of the first generation and $5 \%$ of the second generation defined themselves in this way.

Table 3-Opinions on Self-definition

\begin{tabular}{|c|c|c|c|c|c|c|c|c|}
\hline \multicolumn{2}{|l|}{ Locality } & Turk & \multirow{2}{*}{$\begin{array}{l}\begin{array}{l}\text { Emirdag/ } \\
\text { Posof }\end{array} \\
28\end{array}$} & \multirow{2}{*}{$\begin{array}{l}\text { Belgian } \\
7\end{array}$} & \multicolumn{2}{|c|}{$\begin{array}{l}\text { Belgian } \\
\text { Turk }\end{array}$} & \multirow[t]{2}{*}{ Other } & \multirow{2}{*}{$\begin{array}{l}\text { Total } \\
214\end{array}$} \\
\hline Emirdag & $\mathrm{f}$ & 156 & & & 2 & 21 & & \\
\hline & $\%$ & 72,9 & 13,1 & 3,3 & 0,9 & 9,8 & & 100 \\
\hline \multirow[t]{2}{*}{ Posof } & $\mathrm{f}$ & 141 & 54 & 3 & 0 & 12 & & 210 \\
\hline & $\%$ & 67,1 & 25,8 & 1,4 & - & 5,7 & & 100 \\
\hline \multirow[t]{2}{*}{ Total } & $\mathrm{f}$ & 297 & 82 & 10 & 2 & 33 & & 424 \\
\hline & $\%$ & 70,0 & 19,4 & 2,4 & 0,5 & 7.8 & & 100 \\
\hline Chi-square & \multicolumn{8}{|c|}{$\mathrm{X}^{2}=81,31 \mathrm{df}(5) \mathrm{p}, 000<.02$} \\
\hline Gender & & Turk & $\begin{array}{l}\text { Emirdag/ } \\
\text { Posof }\end{array}$ & Belgian & Bel & urk & Other & Total \\
\hline \multirow[t]{2}{*}{ Female } & $\mathrm{f}$ & 120 & 46 & 6 & 1 & & 11 & 214 \\
\hline & $\%$ & 65,2 & 25,0 & 3,3 & 0,5 & & 6,0 & 100 \\
\hline \multirow[t]{2}{*}{ Male } & $\mathrm{f}$ & 177 & 36 & 4 & 1 & & 22 & 210 \\
\hline & $\%$ & 73,8 & 15,0 & 1,7 & 0,4 & & 9,2 & 100 \\
\hline \multirow[t]{2}{*}{ Total } & $\mathrm{f}$ & 297 & 82 & 10 & 2 & & 33 & 424 \\
\hline & $\%$ & 70,0 & 19,4 & 2,4 & 0,5 & & 7.8 & 100 \\
\hline Chi-square & \multicolumn{8}{|c|}{$X^{2}=9,13 \mathrm{df}(5) \mathrm{p}, 000<.02$} \\
\hline
\end{tabular}


The interviewees were asked to mention the community where they feel they belong to and the reasons for that in order to understand the sense of identity of migrants living in Belgium, as well as the community where they feel they belong to. According to questionnaire results, almost all of the interviewees define themselves as a Turk and they are followed by those who feel that they belong to the two societies. Demir from the first generation and from Posof who defines himself as a Turk says the following to express his opinions;

Honestly, I feel like a Turk. I can never say that I feel like a Belgian. Consequently, being a Turk from Posof... (But you can't say that you belong to the Belgian society, although you were born and bred in here?) No, I can't say that. It's impossible. (Can we ask why?) Why? Because their life styles and cultures are different from those of us. So we don't feel that we belong to here.

Similarly, Nimet from the first generation and from Emirdag who defines herself as a Turk says that her opinions are derived from the characteristics of a closed society in which she lives;

I got married. I came here 29 years ago. Well, a period of 29 years is not short. Because we live in the Turkish society and usually fail to establish a dialogue with Belgians. For them, the Turkish society is everywhere; and Turks are all over, in groceries, greengrocers or coffeehouses.

Sibel from the second generation and from Emirdag says that she feels like a Turk due to exclusionist characteristics of the host country;

I feel like a Turk, because I feel that feeling and they give me that feeling. After all, Belgians don't consider me as a Belgian, either. Even if they pretend, I was born and bred here. You are a Belgian citizen but they don't reflect it this way. They don't give me this feeling.

Doğan from the first generation and from Emirdag defines himself as a Turk and explains the reasons as follows;

I mean, as a Turk and somebody from Emirdag. (Can we ask you why?) Why? Because I know the customs and traditions there and people who live here and my friends are all from Emirdag, but of course we also hang out with people from other localities. Let him be a Turk, somebody from Emirdag or just a human being.

Hayal from the second generation says that she feels like she belongs to the two societies and considers that it is caused by lack of acceptance from the two countries;

I'm in between, because you're a stranger and they look at you with an evil eye. When we go to Turkey, we are considered as German Turks. It hurts me too much, because every year we have an argument there. People say that the outsiders are here. They think that prices increase because of such outsiders. But why are we considered guilty?

Similarly, Gülizar from the second generation who feels like she belongs to the two societies seems to be defining the concept of integration;

I'm in the middle of them. I couldn't switch to any of them. (In other words, how do you feel about it? Let's clarify). Yes, let's clarify. I can neither mingle with Turks, nor with Flemish people. I'm in between them. In terms of education, I'm further inclined to Flemish people but of course I prefer being a Muslim with regard to religion. Besides, I'm not saying that I'm a Turk or this or that. (So on the one hand being a Muslim attracts you?) Yes, but on the other hand I can say that we are inclined towards Flemish people. (Due to the business life?) Yes, due to all of them but mostly because of the life style. In other words, I don't want my children to be raised like a Turk or to put it in a better way, as a villager. I want to raise them more freely and I want them to be more independent. I want them to receive multifaceted education. I must say this.

Gülizar identifies being a Turk with being a villager and wants her children to receive further education than she has and also wants them to be free. According to findings from observations, Gülizar lives just in the middle of Turkish neighborhood and she doesn't visit any friends home except two Turks who are the mothers of her children's friends from school. Furthermore, she indicated in our private conversations that she has never been to the city 
center or movies in the town where she lives in. Stating that her life style is as same as that of Belgians, it's observed that Gülizar's holiday preferences actually differ from those of Belgians. She reported in our private conversations that she has never been to another country except Turkey throughout her holidays. Y1ldiz from the second generation and from Emirdag says that she feels like she belongs to the two societies and says the following;

I can't say that I totally feel like I belong to the Turkish or Belgian society. I also feel like I belong to the Turkish society as well. In other words, during our holidays or celebrations we never forget that we are Turks, but we must also say that we live in Belgium and our children attend Belgian schools. After all, we have Belgian neighbors as well. As a result, they create some impacts on us. So we join them too, and I can't say that I'm totally a Turk. Besides, I was born and bred here. So I must have seen more Belgian traditions and events.

Among the interviewees, Zekiye from the first generation and from Posof is the only person who defines herself as a Muslim says the following;

No, it's my Muslim identity. Being a Turk isn't involved in it at all. I deal with people with my Muslim identity. Being a Turk isn't important. Do you understand me? I feel this way. We are Turks and we are proud of it, but what's important is to be a Muslim.

Zekiye is among a few people from Posof living among those from Emirdag and she often emphasized in our conversations that she was disturbed by the stance of nationalists in the mosque community, as she tutors the group from Emirdag voluntarily. A Turkish origin Belgian politician clearly refers to multiple identities and senses of belonging of Turkish migrants who live in Belgium, which are not often shared by others. He also compares this multiple identity with the monist identity understanding which he believes that exists in Turkish. When his mother was pregnant with him, she came to Belgium and gave birth to him, who builds his identity perception on a ground by saying, "Made in Turkey, born in Belgium."

\footnotetext{
When I introduce myself, so as I am of a Turkish origin, I'm a Turk but I'm also a Belgian, because I was born in Belgium. Although I acquired a Belgian identity not quite early, I live in this country and I have the same background with people living in this country, and thus I feel like I'm connected with this, but on the other hand I love the Brussels-capital region and Brussels very much and I occasionally consider myself as a European. I feel like a Western person but at the same time I feel like I'm from the east, as I listen to Turks. In other words, to sum up in one sentence, I believe that I have multiple identities and maybe a message could be given to people living in Turkey: We can encompass more than one identity.
}

While the interviewees define themselves as Turks, they tried to build their identity perceptions on a ground with such reasons as being from Turkey, having the Turkish origin, as well as customs and traditions, the negative stance of the Belgian people and their inability to accept themselves and living among Turks in an intensive way. Being a Turk is evidently a predominant preference among the interviewees and participants of the questionnaire. It was observed that this choice is considerably expressed in the life in Belgium especially through certain symbols like the Turkish flag. For example, the children wear t-shirts with Turkish flag motifs in special days and festivals and the women wear dresses with the star and crescent and also shawls carrying the flag motives. Store where the clothes with a Turkish flag are sold in the Turkish neighborhoods, attract intensive attention. As a general assessment, defining an identity as Turkish is relatively expressed with the symbols associated with being a Turk, because such a definition is not a conscious stance based on historical and cultural consciousness (Photograph 1,2,3). 


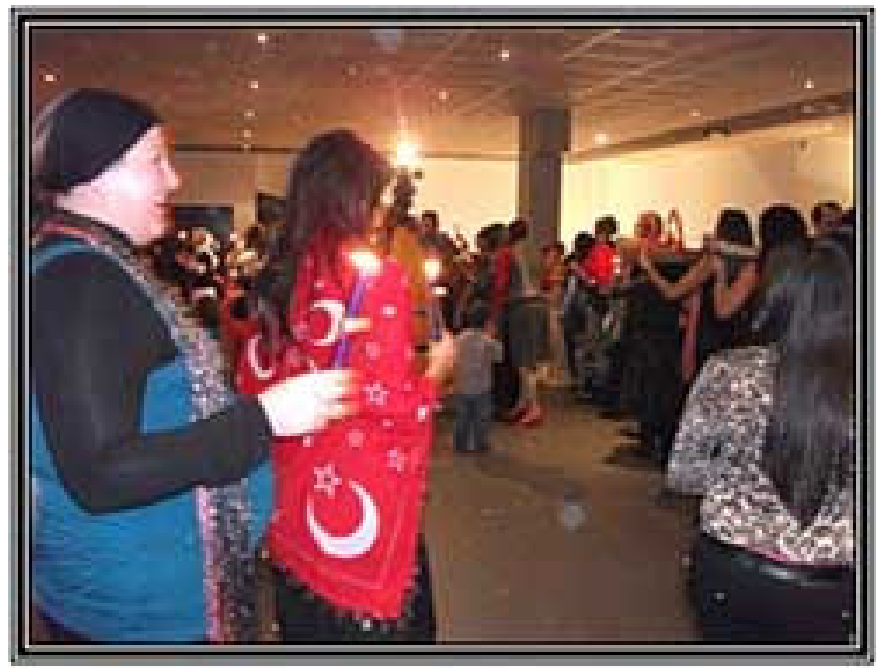

Photograph 1. Women from Emirdag wearing clothes with Tukish flag, Antwerp

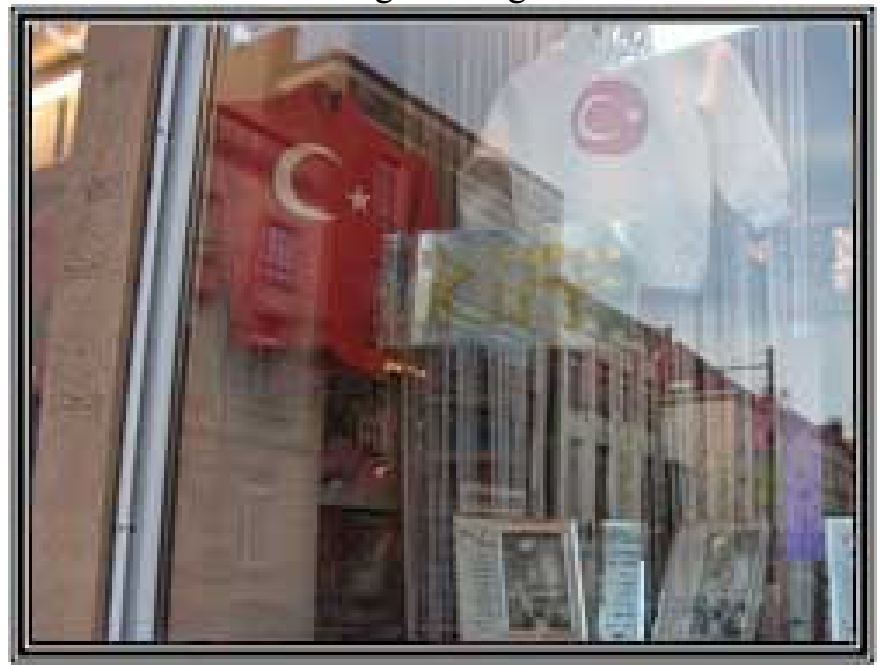

Photograph 2. A Store that Sells Clothes with Turkish Flag, Scharbeek-Brussels

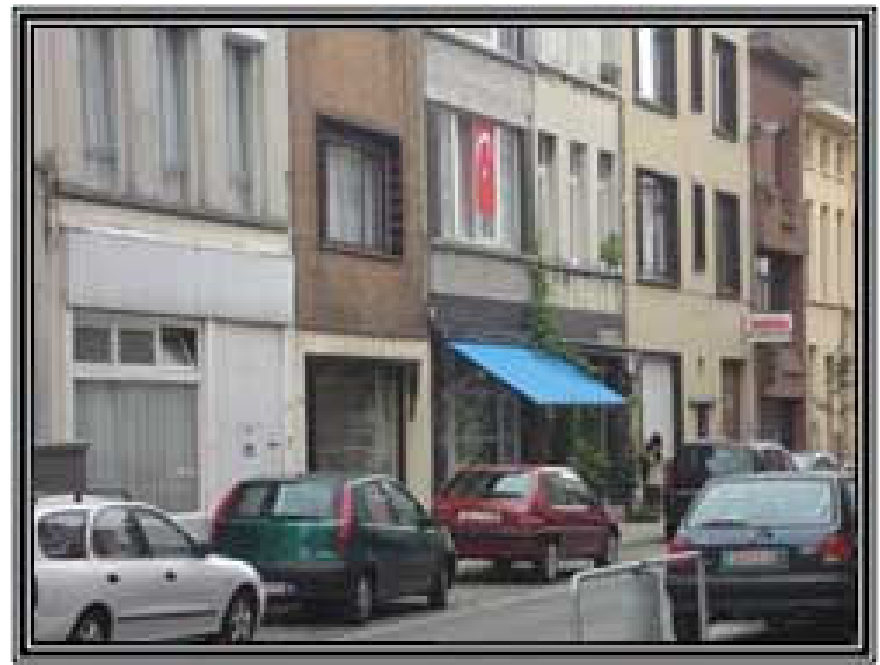

Photograph 3. Turkish Neighborhood, Berchem, Antwerp

Within the concept of the Chi-square analysis of questionnaire participants' answers to questions about a Belgian citizenship in terms of locality, it was found out that there is not a significant relation with regard to localities $\left(\mathrm{X}^{2}{ }_{(5)}=4,76 \mathrm{p}>.05\right)$, gender $\left(\mathrm{X}^{2}{ }_{(3)}=2,01 \mathrm{p}>\right.$ 
$.05)$ and generations $\left(\mathrm{X}^{2}{ }_{(6)}=27,38 \mathrm{p}<.05 ; 58 \%\right)$. There is a higher rate of Belgian citizenship among participants of the questionnaire (87\%), whereas the rate of those who are reluctant to acquire Belgian citizenship is lower (2\%). There is a similar situation in terms of localities as well.

Zekiye from the first generation and from Posof has an approach different from that of Turks with regard to Belgian citizenship but she expresses a basic opinion which is shared by many Belgian Turks in terms of being a Turk-Muslim and Belgian. It could be suggested that Turks' stance on Belgian citizenship is functional;

(Why didn't you acquire a Belgian citizenship?) I don't know. I don't like it. Maybe it's personal but I don't feel comfortable with carrying a Belgian ID card, because it's written on it that you are a Belgian. When you have a look at people's ID cards here, you don't see any Turkish. It's written Belgian there, and believe me or not, it makes me uncomfortable. That's why my children listen to my advice now about this issue. This is the case for my husband, too. Nobody in my family has a Belgian ID card. (Don't you want them to have a Belgian ID card from now on?) No, I don't. Maybe you would laugh at me or condemn me, but my conscience is not clear, and I don't know if it's wrong or an ignorant stance to some people. And some people say that it would facilitate everything. We travel to our country without any visa and it offers many advantages, but I don't agree with them. I feel morally uncomfortable. So now my conscience is clear. I don't put my Belgian ID card in my wallet and go around.

Expressing her opinions about citizenship, Zekiye evaluates the advantages and disadvantages of acquiring a Belgian citizenship as follows:

\begin{abstract}
... No matter what you do, they always consider you as a second class citizen. Even if you are very well-educated, a prominent person with important identity, it's always like this and believe me or not, I am further respected just the way I am. When I go to government offices, why would I try to pretend and fool them about who I am? I'm a Muslim and a Turk. This is what I am. Even if I try, I can't fool you, because you can see me just the way I am. The lack of Belgian citizenship also consists of some disadvantages, but I'm happy. I feel comfortable. Although I cover my head and practice my religion, people show me respect at the government agencies that I visit. For example, in that case they would make concessions to their character, their identity and their religion. Many people try to be like the Flemish here. Some people are ashamed of being a Turk. Besides Islam, some people are ashamed of being a Turk. Some are also ashamed of being a Muslim. In other words, even if they change everything about themselves, they are never respected anywhere as they wish. Indeed, this is the case, because they deceive themselves. Somebody who denies his/her identity also denies his/her everything.
\end{abstract}

A 55-year-old male from Emirdag explains why he is not a Belgian citizen in the notes on the questionnaire form: "I don't want to acquire a Belgian citizenship. It makes me sad, because I feel like I will become a Belgian forever. Thank God the term Turkish is written on my ID card".

The notes on the questionnaire form shows that a 41-year-old female participant says that she has resisted the Belgian citizenship, but then she acquired one lately due to the concrete benefits related with that, saying the following: "Unfortunately I've acquired it recently. I've heard that when you retire as a Belgian citizen, the account is automatically transferred to Turkey, and thus I acquired one".

According to Chi-square results of the participants' answers about how often they visit Turkey (Table 4), all of the participants visit Turkey at certain intervals. 
Table 4-Incidences of Travels to Turkey

\begin{tabular}{|c|c|c|c|c|c|c|}
\hline Locality & & Yearly & Biyearly & $\begin{array}{l}\text { In Periods of } \\
\text { more than Three } \\
\text { Years }\end{array}$ & $\begin{array}{l}\text { A Few } \\
\text { Times in a } \\
\text { Year }\end{array}$ & Total \\
\hline \multirow{2}{*}{ Emirdag } & $\mathrm{f}$ & 118 & 44 & 33 & 19 & 214 \\
\hline & $\%$ & 55,1 & 20,6 & 15,4 & 8,9 & 100 \\
\hline \multirow[t]{2}{*}{ Posof } & f & 96 & 73 & 30 & 11 & 210 \\
\hline & $\%$ & 45,7 & 34,8 & 14,3 & 5,2 & 100 \\
\hline \multirow[t]{2}{*}{ TOTAL } & $\mathbf{f}$ & 214 & 117 & 63 & 30 & 424 \\
\hline & $\%$ & 50,5 & 27,6 & 14,9 & 7,1 & 100 \\
\hline \multicolumn{2}{|l|}{ Chi-square } & \multicolumn{5}{|c|}{$X^{2}=11,689$ df $(3) \mathbf{p ~ , 0 0 9}<. \mathbf{0 2}$} \\
\hline \multicolumn{2}{|l|}{ Gender } & Yearly & Biyearly & $\begin{array}{l}\text { In Periods of } \\
\text { more than } \\
\text { Three Years } \\
\end{array}$ & $\begin{array}{l}\text { A Few } \\
\text { Times in a } \\
\text { Year }\end{array}$ & Total \\
\hline \multirow[t]{2}{*}{ Female } & f & 88 & 51 & 33 & 12 & 184 \\
\hline & $\%$ & 47,8 & 27,7 & 17,9 & 6,5 & 100 \\
\hline \multirow[t]{2}{*}{ Male } & $\mathrm{f}$ & 126 & 66 & 30 & 18 & 240 \\
\hline & $\%$ & 52,5 & 27,5 & 12,5 & 7,5 & 100 \\
\hline \multirow[t]{2}{*}{ TOTAL } & f & 214 & 117 & 63 & 30 & 424 \\
\hline & $\%$ & 50,5 & 27,6 & 14,9 & 7,1 & 100 \\
\hline \multicolumn{2}{|l|}{ Chi-square } & \multicolumn{5}{|c|}{$X^{2}=2,664$ df $(3) p, 446>.05$} \\
\hline \multicolumn{2}{|l|}{ Generation } & Yearly & Biyearly & $\begin{array}{l}\text { In Periods of } \\
\text { more than } \\
\text { Three Years } \\
\end{array}$ & $\begin{array}{l}\text { A Few } \\
\text { Times in a } \\
\text { Year }\end{array}$ & Total \\
\hline \multirow[t]{2}{*}{ First Generation } & $f$ & 119 & 53 & 25 & 18 & 215 \\
\hline & $\%$ & 55,3 & 24,7 & 11,6 & 8,4 & 100 \\
\hline \multirow{2}{*}{$\begin{array}{l}\text { Second } \\
\text { Generation }\end{array}$} & $\mathrm{f}$ & 86 & 62 & 34 & 12 & 194 \\
\hline & $\%$ & 44,3 & 32,0 & 17,5 & 6,2 & 100 \\
\hline \multirow{2}{*}{$\begin{array}{l}\text { Third } \\
\text { Generation }\end{array}$} & $\mathrm{f}$ & 9 & 2 & 4 & - & 15 \\
\hline & $\%$ & 60,0 & 13,3 & 26,7 & - & 100 \\
\hline \multirow[t]{2}{*}{ TOTAL } & $\mathbf{f}$ & 214 & 117 & 63 & 30 & 424 \\
\hline & 100 & 50,5 & 27,6 & 14,9 & 7,1 & 100 \\
\hline \multicolumn{2}{|l|}{ Chi-square } & \multicolumn{5}{|c|}{$X^{2}=11,489 \mathrm{df}(6) p, 074>.05$} \\
\hline
\end{tabular}

As seen on Table 4, more than half of the participants (58\%) visit Turkey once or a few times a year. A significant difference was found with regard to incidence of participants' travels to Turkey in terms of localities $\left(\mathrm{X}^{2}=11,689 \mathrm{df}(3) \mathrm{p}, 009<.02\right)$. Nearly two thirds of migrants from Emirdag (64\%) reported that they visit Turkey yearly or biyearly, whereas half of those from Posof $(51 \%)$ visit Turkey as often as they do. Moreover, a significant difference was not found with regard to incidence of travels to Turkey in terms of gender $\left(X^{2}=2,664 \mathrm{df}(3) \mathrm{p}\right.$ $, 446>.05)$ and generations $\left(X^{2}=11,489 \mathrm{df}(6) \mathrm{p}, 074>.05\right)$.

The observations show that the participants spend their holidays outside Belgium, certainly in Turkey. In this respect, the offices selling flight tickets are the most popular places in Turkish neighborhoods. Similar situations are also evident in Turkey. The requests made by people from Emirdag with regard to new flights from Eskişehir to Belgium are especially taken into consideration. In summer months, the vehicle convoys with Belgian license numbers are typical in Turkey (Photograph 4). The vehicles with Belgian license numbers which are seen on the roads to Emirdag in summer are the indications of ties with Turkey. As the people from Emirdag and Posof who live in Belgium want to spend their summer holidays in Turkey just like other migrants of the Turkish origin, Turkish neighborhoods become empty and lonely in summer months and the mail in mailboxes are observed as the typical scenes of summertime 
(Photograph 5). The interest in and frequency of travels to Turkey correspond to Turkey as well. In the nights, minibuses wait for passengers to get off the plane from Belgium at the airport in Eskişehir to take them up to Emirdag and even to their villages. The drivers standing with posters in their hands to show the village names meet the passengers' demands directed from Belgium to Emirdag (Photograph 6).

According to participants' answers to the question concerning their opinions on returning to Turkey, the majority of them (61\%) don't plan to go back. A significant difference was not found among the opinions in terms of locality $\left(X^{2}=, 84 \mathrm{df}(2) \mathrm{p}, 655>.05\right)$, gender $\left(\mathrm{X}^{2}=2,89\right.$ $\mathrm{df}(2) \mathrm{p}, 235>.05)$ and generations $\left(\mathrm{X}^{2}=5,80 \mathrm{df}(4) \mathrm{p}, 214>.05\right)$.

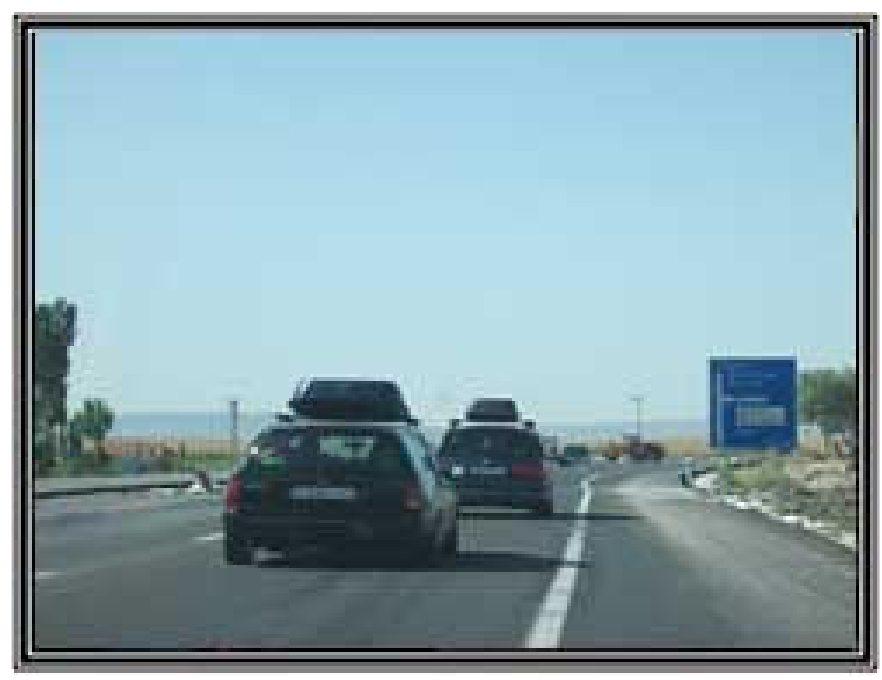

Photograph 4. A vehicle convoy with Belgian license numbers in Turkey

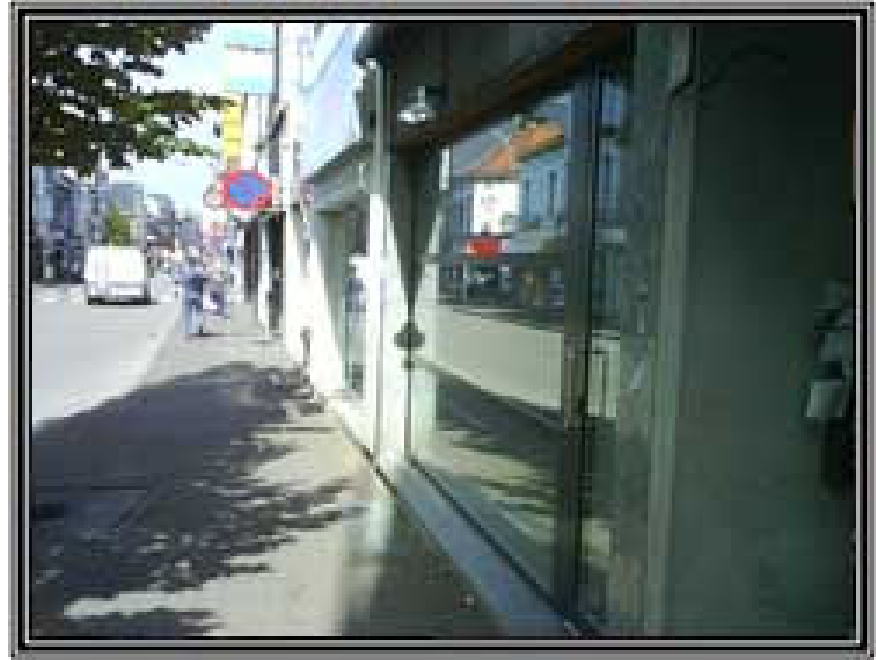

Photograph 5. Turkish Neighborhood in Summer Time, Antwerp 


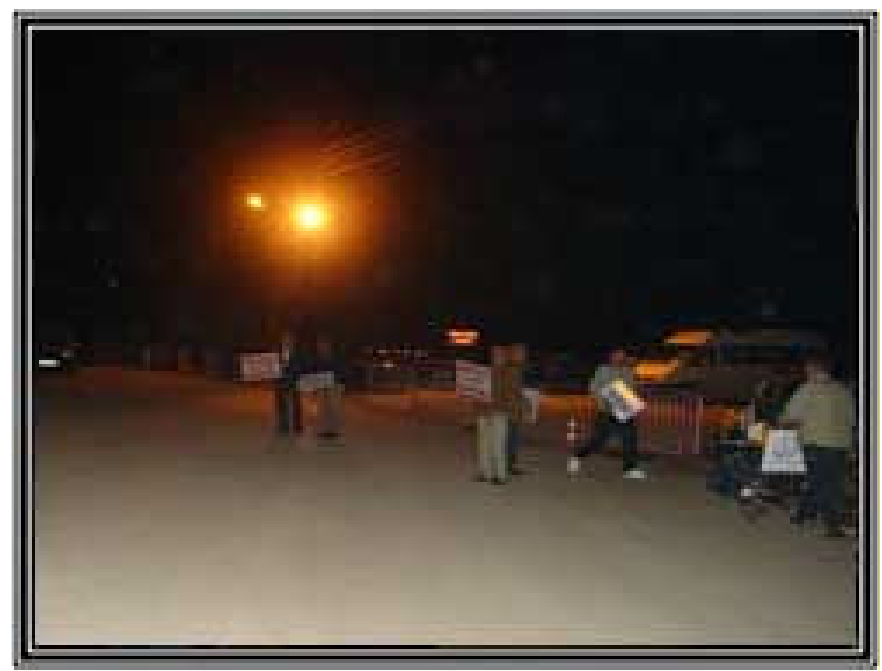

Photograph 6. Minibuses wait for passengers from Belgium at the airport in Eskisehir

As shown by Table 5, there is no significant difference about the reasons of participants' return to Turkey, if they decide to do so, in terms of locality $\left(X^{2}=2,76\right.$ df (3) p .429>.05) and gender $\left(X^{2}=3,49\right.$ df (3) p $\left..321>.05\right)$. Considering the data on Table 5 roughly, the participants indicate their homeland as Turkey (18\%) and also their longing (14\%) as their reasons.

In terms of generations, a significant difference was not found $\left(X^{2}=13,84\right.$ df (6) p .031 $<.05)$. The rate of those indicating their homeland of Turkey as their reason is $20 \%$ in the first generation, $16 \%$ in the second generation and $7 \%$ in the third generation. Furthermore, the rate of indication of longing for Turkey as a reason is $18 \%$ in the first generation, $11 \%$ in the second generation and $13 \%$ in the third generation. A significant difference was not found in the questionnaire participants' answers about their reasons for staying in Belgium with respect to locality $\left(X^{2}=6,03 \mathrm{df}(6)\right.$ p $.11>.05$; $)$, gender $\left(X^{2}=8,63 \mathrm{df}(3)\right.$ p $\left..035<.05 ; \% 25\right)$ and generations $\left(\mathrm{X}^{2}=76,79 \mathrm{df}(6) \mathrm{p} .00<.05 ; \% 41\right)$. The two thirds of participants reported that life was better in Belgium and they have got used living in this country. The one third of them indicated that their decision to stay in Belgium was mainly caused by their children's education. 
Table 5- Views on Reasons for Returning to Turkey

\begin{tabular}{|c|c|c|c|c|c|c|c|c|}
\hline Locality & & & & Poso & & & Tota & \\
\hline & $\mathrm{f}$ & $\%$ & & & $\%$ & $\mathrm{f}$ & & $\%$ \\
\hline Longing & 29 & 13,55 & & & 15,2 & 61 & & 14,4 \\
\hline I'm & 3 & 1,4 & & & 0,5 & & & 0,1 \\
\hline $\begin{array}{l}\text { Temporarily } \\
\text { Here }\end{array}$ & & & & & & 4 & & \\
\hline Our Homeland & 43 & 20,1 & & & 15,7 & 76 & & 18,0 \\
\hline $\begin{array}{l}\text { Life is Hard } \\
\text { Here }\end{array}$ & 7 & 3,27 & & & 4,76 & 17 & & 4,0 \\
\hline Unspecified & 132 & 61,7 & & & 63,9 & 26 & & 62,7 \\
\hline TOTAL & 214 & 100 & & & 100 & 42 & & 100 \\
\hline Chi-square & $X^{2}=2,76$ & ) p,429 & & & & & & \\
\hline Gender & & & & & & & To & \\
\hline & f & $\%$ & & & $\%$ & & & $\%$ \\
\hline Longing & 26 & 14,1 & & & 14,6 & & & 14,4 \\
\hline I'm & - & - & & & 1,6 & & & 0,1 \\
\hline Temporarily & & & & & & & & \\
\hline Here & & & & & & & & \\
\hline Our Homeland & 28 & 15,2 & & & 20,0 & & & 18,0 \\
\hline $\begin{array}{l}\text { Life is Hard } \\
\text { Here }\end{array}$ & 8 & 4,3 & & & 3,8 & & & 4,0 \\
\hline $\begin{array}{l}\text { Here } \\
\text { Unspecified }\end{array}$ & 122 & 66,3 & & & 60,0 & & & 62,7 \\
\hline TOTAL & 184 & 100 & & & 100 & & & 100 \\
\hline Chi-square & $X^{2}=3,45$ & $p, 321$ & & & & & & \\
\hline Generation & & & & & & & & tal \\
\hline & f & $\%$ & f & $\%$ & f & $\%$ & $\mathbf{F}$ & $\%$ \\
\hline Longing & 38 & 17,7 & 21 & 10,8 & 2 & 13,3 & 61 & 14,4 \\
\hline I'm & 3 & 1,4 & - & - & 1 & 6,7 & 4 & 0,1 \\
\hline $\begin{array}{l}\text { Temporarily } \\
\text { Here }\end{array}$ & & & & & & & & \\
\hline Our Homeland & 44 & 20,4 & 31 & 15,9 & 1 & 6,7 & 76 & 18,0 \\
\hline $\begin{array}{l}\text { Life is Hard } \\
\text { Here }\end{array}$ & 7 & 3,2 & 10 & 5,2 & - & - & 17 & 4,0 \\
\hline $\begin{array}{l}\text { Here } \\
\text { Unspecified }\end{array}$ & 123 & 57,2 & 132 & 68,1 & 11 & 73,3 & 266 & 62,7 \\
\hline TOTAL & 215 & 100 & 194 & 100 & 15 & 100 & 424 & 100 \\
\hline Chi-square & $X^{2}=13$, & $\mathbf{p}$, & 05 & & & & & \\
\hline
\end{tabular}

\section{Discussion and Conclusion}

Besides the basic tendency of questionnaire participants with regard to their opinions on identity and sense of belonging, there are some elements which could be defined as inconsistency in terms of the realities of daily life, harmonization and views about the host society. Kaya and Kentel (2008) also mentioned a similar finding and emphasized the disconnection and inconsistency in Belgian Turks' statements in their research. The interpretations made by any Belgian Turk are likely to be self-contradictory. When it comes to his ethnic identity, a nationalist person is occasionally both cosmopolitan and multicultural at the same time. Such inconsistencies could be regarded as an expression of individuals' variable tactics that they have developed in order to resolve their evasive and temporary powers in daily lives and also the problems they face in various fields. Furthermore, as indicated by Mutluer (2006: 49-50), identities are transformed in the process of reconstruction where the nationalism and globalization are shaped, while the identity of Turks in Belgium also change in the course of protecting their values and also accepting new values. This transformation is experienced in a sort of battlefield, where at least two identities are brought 
together, away from the country of origin. As stated by Oksaar (2008: 5), a multilingual individual who is naturally not a member of a homogenous society encompasses identities that reflect different characteristics. A research conducted by Kaya and Kentel (2008: 11) on the Turks in France and Germany suggests that $60-70 \%$ of migrants of the Turkish origin define themselves as a European-Turk or a Turk-European (Turk-German, Turk-French) and point to the hyphenated identities (hybrid identities), but the findings of this study show completely different results. Without ignoring possible differences among the countries, it could be suggested that the hyphenated identities are in the form of Turk-Muslim or a Turk from Emirdag-Posof. According to findings with respect to sense of identity and belonging, the Belgian Turks covered by the sample define themselves mostly and primarily as a "Turk." In line with another finding, they do not define themselves as the "Belgian Turk" and such a definition is not common at all, but evident only in younger generations. The self-definition in accordance with localities where they come from is substantial. This situation is gets denser particularly among those from Posof. The rate of females' self-definition of a Turk is higher, while the definition in terms of locality is higher than that of the male. As the number of generations increases, the rate of self-definition of a Turk decreases. These results are also in parallel with Castells's (2006: 471) finding that the defensive reactions organized around national principles of identity based on borders increase as a result of impacts of globalization. A study conducted by Yağbasan (2009: 132) in Germany shows similar results, revealing that $84 \%$ of participants feel closer to the Turkish nation and $44 \%$ of participants don't consider Germany as their homeland. Although they have been living in Germany for many years, they feel closer to the Turkish nation without considering Germany as their homeland, and this situation could be evaluated relatively. These data which is likely to be welcomed with regard to Turkish society might be open to such an interpretation that the Turks alienate themselves from the German state and nation.

Within the concept of findings, although the Turks in Belgium are living in that country and settled to a great extent, they don't define themselves as Belgian-Turks and consider such hybridization in terms of identity as an attack against their ethnic identity and also think that it's unnecessary. In both rhetoric and real life, it suggests that such a stance is not considered as an obstacle to be living and settled in Belgium without any problem.

Despite the clearness of this sense of belonging among the Turks living in Belgium, Belgium is a country consisting of three states and three nations and encompassing hundreds of thousands of migrants from a wide range of countries and also suffering from internal identity issues. As indicated by Kaya and Kentel (2008: 23) with regard to Brussels, there is a quite diverse and complicated structure of identity. Although Brussels is considered as different from the rest of the country in this regard, the situation is more or less the same in Anvers or Gent. Turks exist with their original ethnic identities among the Walloons, the Flemish people who emphasize their ethnic identities in a stronger way, as well as the Italians, Moroccans, Africans and Poles who are totally integrated with the host community. As defined by Greeley (quoted by Yalçın, 2004: 63-68) in the process of Organization and Sense of Identity Development which constitutes second stage of the cultural integration model, the Belgian Turks exert efforts to protect their language, religion and culture to be safe from assimilation and emphasize the importance of being a Turk as a result of resistance to a dominant culture, as indicated by Martin and Nakayama (2007: 164-166) with respect to stages of ethnic identity development. The policies about migrants which are applied particularly in the Flemish region are also likely to have created an impact on Turks' perception of identity in Belgium. Remaining a Turk equals being assimilated in Belgium. The failure to adopt an approach on the basis of Belgian-Turkish identity might be caused by the lack of confidence 
in Belgium. It can be seen that the perception which foresees tolerance towards minority groups in the Flemish region that follows the Dutch example adopts multiculturalism but which also further emphasizes their "difference" and "separateness" and limits them with their original ethical identity frameworks contribute to the fact that the Turkish identity is maintained.

It is observed that self-definition of a Turk is caused by the efforts for protecting their culture and existing in Belgium with their own culture. The fact that migrants from the second and third generations define themselves as Turks to a lesser degree could be interpreted in such a way that those who have been living in Belgium for a longer period of time or who are born and bred there to experience the process of acculturation lack such a stance of cultural protection and resistance. Nevertheless, self-definition of a Belgian-Turk even among the second and third generations or a greater degree of self-definition of a Turk or in terms of localities could be considered as a result of experiencing the contradiction related with the fact that their parents are regarded as "different" by Belgians and their ethnic origins are different from those of Belgians, rather than resistance to a dominant culture or worries about protecting the ethnic identity. Within this context, it could be defined with an unexamined ethnic identity rather than an ethnic identity which is described by Collier and Thomas (1988 quoted by Jandt, 2010: 25) as identification with a group consisting of a shared heritage and culture with perceive acceptance.

The religion and nationalism play an important role in perceptions of identity, but these values are mostly on the level of symbolic expressions. For example, Cesari's (2003) findings overlap with findings of this study. The rituals have been getting increasingly symbolic and secular among the Belgian-Turks, especially among young people (quoted by Kaya and Kentel, 2008: 139). Considering the cultural awareness and ethnic faithfulness defined by Padilla and Perez (2003: 38), it could be suggested that the level of cultural awareness encompassing proficiency in language of the two cultures, knowledge about historical events which shape the culture, as well as an understanding and appreciation of artistic musical forms of cultures and the value standards which will guide individuals' behaviors is not so high specifically among Turks who live in Belgium. It is seen that the ethical faithfulness based on individuals' natural-born ethnicity and their friends' ethnic group memberships is evident to a great extent. According to findings of Padilla (1980) and as well as Keefe and Padilla (1987) specifically with regard to Mexican immigrants, the cultural awareness decreases starting from the first generation and among the second and third generations, while ethnic faithfulness remains on a higher level for many generations. The next generations' cultural awareness and knowledge are on a lower degree than those of their grandparents, but the level of their ethnic faithfulness is high; they define themselves with their ethnic heritage, make friends from the same ethnicity and join the activities and behaviors which are typically adopted by their ethnic groups (cited in Padilla and Perez, 2003: 38). These are also shown by results of this research. In the second and third generations, the self-definition of ethnic heritage, as well as such characteristics as a group of friends consisting of the countrymen and relatives from the same ethnicity were observed to a great extent. Parekh (2002: 295) argues that the individual members of national identity should not be defined with their common characteristics, namely, on the basis of their ethno-cultural characteristics, and the national identity should be based on the things commonly and jointly shared by them in order to avoid exclusionism and separatism. In this respect, there are obviously some problems in Turkey just like many other countries. Accordingly, this situation poses a problem to migrants of the Turkish origin who live in Turkey. The findings from this study reveal that the Turks living in Belgium define themselves mostly with ethno-cultural terms. Within this context, they define 
themselves with their characteristics, habits, nature, sex customs, traditions, family structures, body language, etc. Those who lack or leave these characteristics on a certain level are being accused of being a Belgian, assimilated and taken away from the Turkish identity. This type of identity perception also affects the social communication processes intensively. This approach which creates negative impacts on social communication processes of the host society is also present in the host society on various levels, and thus a mutually exclusionist perception of identity, as well as an introverted communication world is created. The findings from participants' opinions and the questionnaire results show that being a Turk is evidently the predominant quality in terms of identity perception and that the multiple identities are not reported. Milewski and Hammel (2010: 36) achieved similar findings regarding France, indicating that the Turks who have strong family bonds are not in compliance with Gordon's assimilation theory mainly because their values and behaviors are derived not from being French or a mainstream migrant, but simply from being a Turk. Nevertheless, migrants of the Turkish origin who live in France experience multiple identities at the same time. The "fuzzy transnational identities" mentioned by Maalouf (2000: 35) are inherent in migrants' characteristics and lives, but not reflected on their rhetoric.

Research results show that nearly all of the migrants from Emirdag and Posof have acquired Belgian citizenship. The citizenship is regarded not as an identity issue, but from a functional and pragmatic point of view. Almost all of the participants are Belgian citizens regardless of generation, gender or locality and the number of those who are reluctant about acquiring Belgian citizenship is negligible. Considering it as an important indication of a flexible sense of identity and harmonization with the host country, it could be suggested that these results will significantly function as social communication proficiencies. Despite a strong emphasis on the Turkish identity and frequency of travels to Turkey, being open to a Belgian citizenship and maintaining a life in Belgium as a result of better life conditions could be considered as a functional approach towards the issue. According to findings of Korestelina (2004) who has analyzed acquisition of the identity of a new country among the people with different citizenship, acceptance of the identity of a new country decreases the degree to which ethnic identity is accepted (quoted by Şahin, 2010: 44). But the concept of citizenship is approached from a different perspective in terms of people from Emirdag and Posof who live in Belgium. The aspiration for remaining somehow as a Turk in the course of leading a life in Belgium and also benefiting from political, social and economic opportunities to be offered by the community in which they take place are reflected on being a Belgian citizen. A few participants lacking Belgian citizenship argue that in case they acquire Belgian citizenship, they would lose their Turkish identities and that even if they become a Belgian citizen, the Belgians would not regard them as equal citizens. Nevertheless, the majority of them do not see any threat in this sense, but think of citizenship as a right which should be available. As defined by Glick Schiller et al. (1992), the participants seem to be exemplifying their existence spreading on the two countries and societies, displaying their intention to live in Belgium with a strong perception of Turkish identity and an understanding of hometown, as well as equal citizenship with the host society. Accordingly, the participants, in reference to Kaya and Kentel (2005), maintain their existence in a transnational field which in a sense connects both the homeland and the new country. However, the existence is characterized by being a Turk even in such a transnational field. In a harmonizing field which connects the two identities, there is the original identity which has been brought from homeland and spread into to transnational field rather than an existence composed of multiple identities. They exist not as Belgian-Turks, but as Turks in Belgium. As emphasized by Ogan (2001), Turkish migrants in Europe who try to protect their cultural values without breaking their connections with their homeland as a result of the fear of assimilation have also carried their cultural customs such 
as national and religious festivals, traditions related with marriage and raising a child, as well as division of labor within family with them. As a result of these characteristics, it is seen that they are positioned as a society that resists harmonization. Nevertheless, as observed and found out by Bunnell (2010: 477) with regard to Malay migrants in Liverpool, the Turkish people in Belgium are not outside Turkey, Emirdag or Posof, but they exist in two places at the same time and experience the transnational socials fields mentioned by Levitt and Glick Schiller (2004).

\section{References}

Bunnell, T. (2010). Routes of identity: Malay Liverpool and the limits of transnationalism. Pacific Affairs, 83 (3), 459-479.

Castells, M. (2006). Enformasyon çă̆ı: ekonomi, toplum ve kültür, III.Cilt Binyılın sonu. (Çev. Ebru Kılıç). İstanbul Bilgi Üniversitesi Yayınları.

Chen, G.M. (2005). A model of global communication competence. China Media Research, $1(1), 3-11$.

Djelic, M. ve Quack, S. (2010). Transnational communities: shaping global economic governance. Cambridge: Cambridge University Press.

Faist, T. (2000). The Volume and dynamics of international Migration and Transnational Social Spaces. Oxford: Oxford University Press.

Faist, T. (2003). Uluslararası göç ve ulusaşırı toplumsal alanlar. (Birinci Basım), Ankara: Bağlam Yayıncılık.

Gielis, R. (2009). A global sense of migrant places: towards a place perspective in the study of migrant transnationalism. London: Blackwell Publishing Ltd \& Global Networks Partnership.

Glick Schiller, N., Basch, L.;Blanc-Szanton, C. (1992). Transnationalism: A new analytic framework for understanding migration. Towards a transnational perspective on migration, (Ed.Glick Schiller, N., Basch, L. and Blanc-Szanton, C.) New York: New York Academy of Sciences. pp. 1-24.

Hall, S. ve Du Gay, P. (Ed.) (1996). Questions of cultural identity. London: Sage Publications.

Haralambos, M. ve Holborn, M. (1995). Sociology: themes and prspectives. London: Collins Educational.

Jandt, F. E. (2010). An introduction to intercultural communication: identities in a global community. California: Sage Publications.

Kaya A. ve Kentel, F. (2005). Euro -Türkler Türkiye ile Avrupa Birliği arasında köprü mü, engel mi? Birinci Basım. İstanbul: Bilgi Üniversitesi Yayınları.

Kaya A. ve Kentel, F. (2008). Belçika Türkleri Türkiye ile Avrupa Birliği arasında köprü mü, engel mi? Çev: S. Gökçe. Birinci Basım. İstanbul: Bilgi Üniversitesi Yayınları.

Lewitt,P. ve Glick Schiller, N. (2004). Conceptualizing simultaneity: a transnational social field perspective on society. International Migration Review, 38 (3), pp. 1002-1039.

Maalouf, A. (2000). Ölümcül kimlikler. İstanbul: YapıKredi Yayınları.

Maalouf, A. (2009). Çivisi çıkmış dünya. Çev: Orçun Türkay. İstanbul: YapıKredi Yayınları. 
Milewski, N. ve Hamel,C. (2010). Union formation and partner choice in a transnational context: the case of descendants of Turkish immigrants in France. International Migration Review, 44 (3), 615-658.

Martin, J. N. ve Nakayama, T. K. (2007). Intercultural communication in contexts. New York: McGraw-Hill.

Mutluer, N. (2006). Küçük ve orta ölçekli girişimcilerin Londra diasporasında modern Türk kimliğini yeniden inşası. Batı Avrupa'da Türk dış göç sürecinin güncel boyutları. (Ed. B. Doyuran Kartal), Eskişehir: Anadolu Üniversitesi Yayınları, s.25-50.

Ogan, C. (2001). Communication and identity in diaspora: Turkish migrants in Amsterdam and their use of media. Boston: Lexington Books.

Oksaar, E. (2008). Kültürlerarası iletişim bağlamında kültür kuramı. (Çev. A.Selçuk). Konya: Çizgi Kitabevi

Orozco, M.; Garcia-Zanello, E. (2009). Hometown associations: transnationalism, philanthropy, and development. Brown Journal of World Affairs Spring/Summer, 15 (2).

Padilla, A. ve Perez,W. (2003). Acculturation, social identity, and social cognition: a New perspective. Hispanic Journal of Behavioral Sciences, 25,(1), 35-55.

Parekh, B. (2002). Çokkültürlülüğü yeniden düşünmek: kültürel çeşitlilik ve siyasi teori. Çev. B.Tanrıseven. Ankara: Poenix.

Shi, Y. (2005). Identitiy construction of the Chinese diaspora, ethnic media use, community formation and the possibility of social activism. Journal of Media and Cultural Stdudies, 19 (1).

Şahin, B. (2010). Almanya'daki Türkler. Ankara: Phoenix Yayınevi.

Turkish Embassy in Brussels (2014). Türkiye-Belçika Siyasi İlişkileri. http://bruksel.be.mfa.

.gov.tr/ShowInfoNotes.aspx?ID=121215 (01.04.2014).

Vertovec, S. (2001). Transnationalism and identity. Journal of Ethnic And Migration Studies, 27 (4), 573-582.

Vertovec, S. (2004). Cheap calls: the social glue of migrant transnationalism. Global Networks, 4 (2), 219-224.

Yağbasan, M. (2009). Kültürlerarası iletişim ve diyalogun Almanya özelinde analizi. eJournal of New World Sciences Academy, (4/1), 136-2.

Yalçın, C. (2004). Göç sosyolojisi. Ankara: Anı Yayıncılık.

Zontini, E. (2010). Transnational families, migration and gender: Moroccan and Filipino women in Bologna and Barcelona. New York: Berghahn Books 